УДК 821.161.2-93.09]-054.7

Варданян Марина, кандидат філологічних наук, доцент Криворізький державний педагогічний університет

\title{
УКРАЇНСЬКА ДІАСПОРНА ЛІТЕРАТУРА ДЛЯ ДІТЕЙ ТА ЮНАЦТВА ЯК ПРЕДМЕТ ТЕОРЕТИКО-КРИТИЧНИХ ДОСЛІДЖЕНЬ
}

Ця стаття входить до ичклу публікацій автора, щэо присвячені украӥнській діаспорній літературі для дітей та юначтва. У ній увага зосереджена на дослідженні критичних матеріалів $i$ теоретичних праць, щсо торкаються як осмислення категорій "дитячої літератури» й пов'язаних із нею літературознавчих проблем, так $i$ присвячені власне літературі для дітей та юначтва письменників украйнського зарубіжжя.

Ключові слова: література для дітей та юнацтва, украйнська діаспора, літературознавство.

Vardanian M. Ukrainian Diaspora literature for children and youth as the subject of the theoretical and critical research.

This paper represents the series of publications devoted to the Ukrainian Diaspora literature for children and youth. It focuses on studying critical materials and theoretical works that cover the categories of "literature for children" and related literary problems, as well as the actual issues of literature for children and youth of Ukrainian Diaspora writers.

The paper notes that the comprehension of the literature for children and youth should be investigated in the following priority ways: theoretical ones considering and formalizing the categories and definitions, in particular, "literature for children" and "literature for children and youth", tasks and functions of "literature for children", its period classification; historical and literary and typological ones, covering the actual consideration of works written for this reader group.

The article deals with the Ukrainian Diaspora literature for children and youth, which has not been the subject of a thorough study. Present-day research studying the Ukrainian Diaspora heritage can be divided into several groups: biographical papers, analyzing the works of writers for the "adult" reader, in particular E. Andiievska, Ivan Bagrianyi, V. Vynnychenko, Vera Vovk, I. Kachurovskyi, B. Lepkyi, L. Mosendza, S. Cherkasenko; critical works studying the literature for children written by emigrant writers, which include reviews of books, book prefaces, work interpretations, life and work reviews. Textbooks in literature for children take a special place in the contemporary literary discourse. They represent the "child" works of the Ukrainian Diaspora writers. The analysis of these works gives the following observations: on the one hand, the Ukrainian literature for children and youth can take its own special place in the Ukrainian literature, on the other hand, the Ukrainian Diaspora literature for children and youth is the discovery of the Other Ukraine different from the mainland Ukraine.

Studying the research papers on the issues of the Diaspora literature for children allows tracing the formation of critical thinking among the Ukrainian Diaspora writers. In particular, the 
categories "literature for children" and "literature for children and youth" are defined as synonymous. This concept includes understanding of literature for children as the literature actually FOR children, ABOUT children, and even ON BEHALF of the little reader (Leonid Poltava).

The attention of the Ukrainian Diaspora critique researchers is mostly paid on the problems of period classification of the literature for children, which is presented in integrity with mainland Ukrainian literature for children and youth, though it is carried out abroad. Thus, the writers consider the Diaspora literature for children written in emigration and literature for children written in Ukraine as the whole literary process. Critics try to demonstrate both the continuity of its development, its connection with the native land and the contrast of ideology and values.

The article also emphasizes the heterogeneity of literature for children and youth. The Ukrainian Diaspora critics (B. Goshovskyi, R. Zavadovych, L. Khraplyva-Shchur) determine the following periods: pre-school books, school books and books for adolescents and youth. This division is constructed to the idea of the continuation implemented by the theorists of the Ukrainian Diaspora literature for children.

The peculiarities of the children's books for different age groups are the subject of consideration in popular reviews of that time. They are often published on the pages of the journal "Our Life". The following structure is typical for them: the definition of an age group, the disclosure of the characters, defying the issues, the assessing of artistic design and illustrations of the book.

Among the problem topics in the research papers on the Diaspora literature for children are the following: the functions and role of this literature, which is meant to preserve the national and cultural component of Ukrainians.

The conclusions emphasize that the study of the Ukrainian Diaspora literature for children and youth can be implemented in several aspects: the comprehension of modern Ukrainian Diaspora literature for children; typological survey and as the part of the native land literature.

Key words: literature for children and youth, Ukrainian Diaspora, literary studies.

В українському літературознавстві спостерігається постійний науковий інтерес до такої його галузі як література для дітей та юнацтва. Наразі можна вести мову, що дитяча література не стоїть на маргінесах «дорослої» літератури. Серед пріоритетних напрямків досліджень сучасних науковців як формування та закріплення категорій і дефініцій в осмисленні літератури для дітей та юнацтва, так і власне розгляд творів, написаних для цієї категорії читачів. Проте не ставала предметом теоретично-критичного осмислення література для дітей та юнацтва письменників української діаспори. Насамперед, опрацювання цієї теми ускладнено тим, що українські бібліотеки не містять ані повних зібрань книг, ані відомостей про письменників, які творили на ниві дитячої літератури в українському зарубіжжі. Проте, на наш погляд, ця література має неабияке значення у вирішенні важливих літературознавчих та загальнотеоретичних проблем: на жанрово-стильовому рівні зокрема та в аспекті становлення літературного процесу XX ст. загалом. 
У цій статті ми розглянемо теоретичні дослідження, що торкаються окреслення дефініцій «дитячої літератури», iï періодизації тощо в працях сучасних українських учених та критичних розвідках українців зарубіжжя. Тим самим, ми прагнемо засвідчити, з одного боку, що література для дітей та юнацтва в Україні посіла своє повноправне місце в літературознавчій галузі, а 3 іншого наголосити, що українська діаспорна література для дітей та юнацтва $\epsilon$ відкриттям українського Іншого для материкової України, що може стати основою для подальших грунтовних студій.

Останні дослідження дають змогу говорити про кілька напрямів осмислення літератури для дітей та юнацтва. Насамперед, це теоретичний напрям, що окреслює термінологічний апарат дитячої літератури та ऑii періодизацію (докладно див.: [1; 7], [2], [12], [13], [17], [22] тощо). На сьогодні дослідники не мають одностайної думки щодо дефініцій «дитяча література», «література для дітей та юнацтва», «дитяче читання», «дитяча творчість». Відправним для літературознавців є визначення Л. Киличенко, яка, власне, й започаткувала дискусію навколо означених термінів у своєму посібнику «Українська дитяча література»: «Дитяча література чи література для дітей- це та література, яка відповідає рівневі дитячих знань, їхньому життєвому досвіду, психологічному розвиткові, має відповідну тематику й технічне оформлення» [14, с. 16]. Дослідниця паралельно вживає поняття дитяча література та література для дітей, адже вони мають спільну рису - те, щуо написано спеціально для дітей; все інше, зокрема і твори дітей, належать до дитячої творчості [14, с. 16].

Іншої позиції дотримується Ю. Ковалів. На переконання дослідника, дитяча література охоплюе усну ци писемну словесність, творену дітьми, перші спроби пера юних початківиів, а література для дітей - створюється дорослими письменниками для молодшого читача [19, с. 285].

Підтримуючи позицію вченого, В. Кизилова окреслила дефініції «література для дітей та юнацтва», «література про дітей», «дитяча література» як такі, що не є «остаточно внутрішньозамкненими системами, а ивидие 
частинами однієї метасистеми, щзо постійно взаємодіють $i$ взаємозбагачуються» $[13$, с. 10].

У критичній та теоретичній літературі української діаспори не розрізнено поняття «дитяча література» та «література для дітей». В одних джерелах вживається термін «література для дітей» [25, с. 1333], «література для дітей та мо́лоді» [23, с. 672], в інших - «дитяча література» [6]. Згадувані поняття однаковою мірою вживані власне в Статуті Об’єднання працівників дитячої літератури ім. Л. Глібова в його редакції 1961 року. А один із його членів та автор багатьох творів для дітей та юнацтва Леонід Полтава так означив цю дефініцію: «Дитяча література - це література д л я, п р о і навіть в $і$ д імені малого читача» $[24$, с. 273].

Якщо звернутися до англомовних джерел, то розбіжності в семантиці понять «дитяча література», «література для дітей» не зустрічаються. У низці англомовних наукових періодичних видань Children's Literature in Education, International Research in Children's Literature, History of Education and Children's Literature, Bookbird: A Journal of International Children's Literature аналізуються художні твори для дітей та порушуються проблеми читання в освіті. Тут дослідники послуговуються терміном «children's literature» на позначення літератури або книг для дітей [36, с. 120-121]. Переклад цього терміну українською мовою як «дитяча література» або «література для дітей» $\epsilon$ рівнозначним та значною мірою справою смаку. У розмові 3 професором Я. В. Шрамком про відмінність цих дефініцій, ми прийшли до розуміння, що в наданні переваги першому варіанту як більш усталеному, другий варіант може розумітися як одне з можливих (синонімічних) пояснень першого.

Теоретичний блок охоплює також періодизацію дитячої літератури. На сьогодні є кілька концепцій становлення літератури для дітей (докладно див.: [12, с. 13-17]). Попри розходження в етапах становлення української дитячої літератури, усі вони розглядають літературу для дітей, що формувалася на материковій Україні, та в жодній не згадується дитяча діаспорна література. 
Натомість в українських діаспорних джерелах розвиток дитячої літератури охоплює всі ïi етапи як в радянській Україні, так і в еміграції. Перші спроби подати узагальнену картину української дитячої літератури в діаспорі належать Б. Гошовському в його статті «У боротьбі за дух нації в душах дітей» [4, с. 22-32], що згодом мала доповнення [6]. Критик визначив десять періодів дитячої літератури, що сформували структуру розділів його монографії [6]: 1) український дитячий фольклор; 2) дитяча література у світі; 3) від літописних переказів до байкарів XVII - XIX ст.; 4) Марко Вовчок та Б. Грінченко; 5) від «Читанки» М. Шашкевича 1850 р. до «Дзвінка» 1890 1914 рр.; 6) «Молода Україна» О. Пчілки; 7) розмах 1917 - 1919 рр., «контроль партії» та жертви червоного терору; 8) дитяча література поза УСРС між двома війнами; 9) у роки війни 1939 - 1945 рр.; 10) дитяча література у «Вільному Світі», ОПДЛ, «Веселка» та інші видання.

Більш узагальнену періодизацію містить публікація в «Енциклопедії українознавства», у якій література для дітей бере свої початки з фольклору та давньої літератури (до кінця XVIII ст.), етапом становлення власне дитячої літератури визначено нову українську літературу XIX ст., а в XX ст. два вектори iї розвитку - національна українська література для дітей в еміграції та література за «совєтського періоду» [25, с. 1333-1369]. Розглядаючи дитячу літературу в еміграції та радянській Україні як єдиний літературний процес, теоретики прагнули, 3 одного боку, засвідчити безперервність іï розвитку, зв’язок із рідним краєм та, 3 іншого - контраст ідеології, цінностей. В осмисленні двох останніх етапів розвитку української літератури для дітей підтримуємо позиції у вказаних дослідженнях української діаспори.

Велику увагу письменники й критики українського зарубіжжя приділяли проблематиці функцій та завдань дитячої літератури в еміграції. На неї покладалася роль збереження національної й культурної складової українців. Зокрема, Б. Гошовський розглядав літературу для дітей та юнацтва як духовного провідника [5, с. 118]. 
Р. Завадович підтримав Б. Гошовського у своїх публікаціях «Наказ хвилини» [10] та «Через землю та любов - до Батьківщини» [11]. У них ішлося про формування в дітей української ідентичності через літературу, починаючи 3 дошкілля, задля протидії деструктивним тогочасним впливам та плекання любові до Батьківщини. «Література, - наголошував Р. Завадович, - дає виховно спрямовану форму краси» [11, с. 4].

Тому українськими письменниками в еміграції надавалася перевага національно-патріотичнім, історичнім та біографічним темам творів для дітей та юнацтва. Адже впродовж тривалого часу українські митці різних поколінь у діаспорі дотримувалися спільної позиції щодо ролі дитячої літератури, україноцентричної за своєю суттю: «Ані в чужій школі, ані з чужої книжки не зачерпнеш українського духа» [21, с. 51], чим акцентували на ії значенні як чинника формування національної ідентичності в діаспорі.

Інший напрямок досліджень із дитячої літератури - компаративні та історико-літературні праці, присвячені художній літературі для дітей. У них дослідники висвітлюють своєрідність літературної казки (Г. Сабат), поетику густативів у сучасній казці (С. Ковпік), особливості п’єси-казки (А. Новиков), світ дитинства в прозі українських письменників-шістдесятників (А. Гурбанська, О. Чепурна), жанрову специфіку сучасної української літератури для дітей (В. Кизилова, Л. Овдійчук та ін.). Якщо дослідники й торкаються творчості окремих еміграційних письменників, то не виокремлюють їх із контексту дитячої літератури радянської України. Водночас це сприяє усвідомленню єдності літературного процесу XX ст., зокрема діаспорної та материкової літератури для дітей та юнацтва, а також говорить про нерозкритість проблематики української діаспорної дитячої літератури як цілісного самобутнього явища, коли вона зазвичай обмежується декількома персоналіями, котрі творили переважно для дорослого читача (Е. Андієвська, Іван Багряний, В. Винниченко, Б. Лепкий).

Зокрема, розглядаючи аспекти становлення жанру літературної казки, О. Гарачковська, у загальному контексті, поряд із українськими радянськими 
казкарями називає постаті А. Короліва-Старого, Олександра Олеся, які працювали на ниві дитячої літератури в еміграції [3]. А у своїй хрестоматії української літератури для дітей дослідниця разом із письменниками материкової України подає твори Е. Андієвської, Івана Багряного, В. Винниченка, Р. Завадовича, Б. Лепкого, Олександра Олеся, С. Черкасенка [31].

Натомість у хрестоматіях [29] та [32] твори для дітей митців української діаспори виокремлено. Окрім уже відомих постатей, В. Винниченка, Б. Лепкого, Олександра Олеся, яких розглянуто в контексті материкової України, А. Мовчун подає такі прізвища: Іван Багряний, Л. Бризгун-Шанта, Віра Вовк, Р. Завадович, Ольга Мак, І. Качуровський, Олекса Кобець, Катерина Перелісна, Леонід Полтава, Л. Храплива-Щур, Дмитро Чуб, М. Щербак. Деякі постаті маловідомі українському читачеві, а дехто не асоціюється 3 дитячою літературою (Іван Багряний, Віра Вовк, І. Качуровський). Разом із художніми творами дослідниця упорядкувала біографії митців.

В іншій хрестоматії - «Українське дошкілля» - дібрано твори представників української радянської доби та використано набутки діаспорної літератури, що відображають засади українського національного виховання [33]. У збірнику «Український декламатор» презентується єдність літературного процесу, який відбувався на материковій Україні та в зарубіжжі у XX ст. Його укладачі наводять не лише поезії для мо́лоді українських письменників, а й класиків світової літератури, зокрема Дж. Байрона, Р. Кіплінга, очевидно, засвідчуючи високий рівень української літератури для дітей та юнацтва, що вміщує як національні, так і загальнолюдські цінності [34]. Доповненням до поезій $є$ наведені основні віхи життя та творчості письменників, твори яких увійшли до збірника. Поезіями української діаспори для дітей презентована також третя книга «Листок з вирію. Журавлики» [18], У якій подано понад вісімдесят біографій письменників, що зробили свій внесок у розвиток дитячої літератури. 
Різноманіття жанрів дитячої літератури в діаспорі - казки, оповідання, нариси, повісті, п’єси, поезії - представлено в хрестоматії «I в мене був свій рідний край...» [8], у якій не лише подаються короткі біографічні довідки, а наводиться бібліографічний покажчик літературної спадщини української діаспори для дітей та юнацтва.

Попри такі здобутки, дитяча література української діаспори наразі досліджена не повною мірою. Розвідки, у яких представлений той чи той діаспорний письменник, котрий писав і для дітей, можна розділити на кілька груп: біографічні («Українська діаспора: літературні постаті, твори, біобібліографічні відомості» [30], «25 поетів української діаспори» [26], «Сто дванадцять розповідей про письменників» [16]); дослідження, y яких аналізуються твори письменників для «дорослого» читача, зокрема Е. Андієвської, Івана Багряного, В. Винниченка, Віри Вовк, І. Качуровського, Б. Лепкого, Л. Мосендза, С. Черкасенка (тут українські дослідники зазвичай не звертаються до розгляду «дитячої» спадщини митців та згадують твори для дітей принагідно); критичні роботи, присвячені аналізу дитячої художньої літератури еміграиійного письменника, що є найменшою групою. Сюди можна віднести рещензї̈ на книги (О. Забарний про «Каміння під косою» Ольги Мак [9]), передмови до книг (Олекса Кобець «Ряст» [35] тощо), аналізи творів Ольги Мак [27], Леоніда Полтави [20] тощо, огляд життя i творчості Л. Бризгун-Шанти [28], Р. Завадовича [15] тощо.

Дитяча література діаспори не зазнала системного вивчення і власне в українському зарубіжжі. У самій діаспорі виходили окремі публікації (рецензії, збірки статей, енциклопедичні статті, спогади, передмови до книг), у яких критики здійснювали огляд окремих творів. Важливим аспектом тогочасних критичних розвідок ставало визначення неоднорідності літератури для дітей та юнацтва. Ця література розмежовувалася на три розділи - дошкілля, шкільний вік та книги для підлітків і молоді, чим реалізовувалася ідея наступності, підтримувана в колах української інтелігенції зарубіжжя. 
Особливості дитячої книжки для різних вікових категорій $є$ предметом розгляду в популярних на той час рецензіях, що часто публікувалися на сторінках журналу «Наше життя». Для них була притаманна така структура: визначення вікової групи, розкриття образів героїв, формулювання проблематики, оцінювання художнього оформлення та ілюстрацій до книги.

Коротко підсумуємо. Дослідження, присвячені літературі для дітей та юнацтва характеризується своєю різнонаправленістю. Наразі науковці намагаються сформувати термінологічну складову цієї порівняно молодої галузі літературознавства. У той же час плідними є здобутки у вивченні жанрово-тематичної специфіки літератури для дітей та юнацтва, як української, так і зарубіжної. У цьому процесі, на наш погляд, варто також відвести належне місце українській діаспорній літературі для дітей та юнацтва.

Серед перспективних векторів майбутніх студій про українську діаспорну літературу для дітей та юнацтва окреслимо такі: дослідження може отримати продовження в осмисленні сучасної дитячої літератури українського зарубіжжя; цікавим видається типологічний аспект досліджень літератури для дітей та юнацтва української діаспори, що може бути реалізовано через зіставлення творів різних жанрів у літературі української діаспори задля окреслення жанрових дефініцій дитячої літератури загалом, а також через зіставлення художніх рішень у постановці різних тем, які втілені у творчості українських діаспорних письменників та представників інших національних літератур; перспективним напрямком убачаємо системне вивчення персоналій письменників української діаспори в літературі рідного краю, адже ці твори не лише відкривають багату та самобутню на таланти літературу певного регіону України, а й є посланням до сучасників - цінувати рідну землю, свою малу Батьківщину - та не захоплюватися надмірно чужим, оскільки еміграція - це постійна боротьба за існування та самопрезентацію. 


\section{Література}

1. Богданець-Білоскаленко Н. I. Українська дитяча література. Маловідомі твори українських письменників II половини XIX ст. - I половини XX ст. : навчальний посібник / Н. І. Боганець-Білоскаленко. - Київ : Видавничий Дім «Слово», 2009. - 280 с.

2. Варданян М. В. Дитяча література : навчально-методичний посібник / М. В. Варданян. - 2-е вид., випр. і допов. - Кривий Ріг : Видавничий центр КДПУ, 2018. - 128 с.

3. Гарачковська О. О. Українська літературна казка 70-90-х років XX ст.: сюжетно-образна структура, хронотоп : автореф. дис. ... канд. філол. наук / О. О. Гарачковська. - Кіровоград, 2008. - 18 с.

4. Гошовський Б. У боротьбі за духа нації в душах дітей / Б. Гошовський // На сторожі душі української дитини. - Париж - Нью-Йорк Торонто - Буенос-Айрос - Мельборн : ОПДЛ, 1951. - С. 22-32.

5. Гошовський Б. Українська дитяча література / Б. Гошовський // Збірник МУР. - 1946. - № 2. - С. 118.

6. Гошовський Б. Українська дитяча література: спроба огляду i проблематика / Б. Гошовський. - Торонто - Нью-Йорк : ОПДЛ, 1966. - 116 с.

7. Дитяча література. Твори українських письменників II половини XX початку XXI століть : навчальний посібник / упоряд. Н. I. БогданецьБілоскаленко. - Київ : Видавничий Дім «Слово», 2011. - 480 с.

8. «І в мене був свій рідний край...» : хрестоматія української діаспорної літератури для дітей та юнацтва / упоряд. М. В. Варданян. - Кривий Ріг : Видавництво «Діонат» (ФО-П Чернявський Д. О.), 2018. - 504 с.

9. Забарний О. Шляхом спокути (Рецензія на повість Ольги Мак «Каміння під косою») / О. Забарний // Дивослово. - 1996. - № 11. - С. 57-59.

10.Завадович Р. Наказ хвилини / Р. Завадович // Українські вісті. - 1948. № 46. - C. 4 .

11.Завадович Р. Через землю і любов до Батьківщини / Р. Завадович // Українські вісті. - 1948. - № 43. - С. 4. 
12. Качак Т. Українська література для дітей та юнацтва : підручник / Т. Качак. - Київ : ВЦ «Академія», 2016. - 362 с.

13.Кизилова В. В. Жанрово-стильова еволюція прози для дітей та юнацтва другої половини XX століття : автореф. дис. ... д-ра філол. наук / В. В. Кизилова. - Київ, 2014. - 40 с.

14.Киличенко Л. Українська дитяча література / Л. Киличенко. - Київ : Вища школа, 1988. - 264 с.

15.Кирпа Г. Князь Роман зі Славної [про українського письменника Романа Завадовича] / Г. Кирпа // Соняшник. - 1993. - № 3-4. - С. 22-23.

16.Кодлюк Я. П. Розповіді про письменників : посібник для вчителя початкових класів / Я. П. Кодлюк, Г. С. Одинцова. - Тернопіль : Підручники і посібники, 1997. - 128 с.

17.Костюченко В. Літературними стежками. Нарис історії української літератури для дітей XX століття / В. Костюченко. - Київ : К.І.С., 2009. - 344 с.

18.Листок із вирію: поезія української діаспори / упоряд. Галина Кирпа, Дмитро Чередниченко // Київ : Етнос, 2011. - Кн. 3 : Журавлики : поезія української діаспори для дітей. -608 с.

19.Літературознавча енциклопедія : у 2-х т. / авт.-уклад. Ю. І. Ковалів. Київ : ВЦ «Академія», 2007. - Т. 1. - 608 с.

20.Мацько В. П. Концепція людини і світу в українській діаспорній прозі XX століття : автореф. дис. ... д-ра філол. наук / В. П. Мацько - Київ, 2010. $36 \mathrm{c}$.

21.Пакуляк В. П’ять літер ОПЛДМ / В. Пакуляк // Ми і наші діти. 1983. - Ч. 10. - C. $50-51$.

22.Папуша О. Дитяча література як маргінес літературознавчої теорії: до проблеми конституювання об'єктів наукового дискурсу / О. Папуша // Слово і час. - 2004. - № 12. - С. 20-26.

23.Нитченко Д. 3 літературно-видавничого життя в Австралії: бібліографічна розвідка / Д. Нитченко ; ред. М. Павлишин [та ін.] // Українці в Австралії. - Мельборн, 1998. - Том II. - С. 656-686. 
24.Полтава Л. 3 думок про творчість для дітей / Л. Полтава // Ми і наші діти. - 1965. - С. 273-274.

25. Р. М. Література для дітей // Енциклопедія українознавства. Словникова частина (ЕУ - II). - Париж - Нью-Йорк, 1962. - Т. 4. - С. 13331369.

26.Слабошпицький M. 25 поетів української діаспори / М. Слабошпицький. - Київ : Видавництво «Ярославів Вал», 2006. - 728 с.

27.Смірнова Н. Історичні казки Ольги Мак : семантичний рівень / Н. Смірнова // Вісник Черкаського університету : серія «Філологічні науки». 2013. - № 5. - C. 57-62.

28.Сорока П. Леся Бризгун-Шанта, або в пошуках золотого горішка. Нарис життя і творчості / П. Сорока. - Тернопіль : Стаф Софт, 1999. - 124 с.

29.Українська дитяча література : хрестоматія / вступна ст. та упоряд. Л. П. Козачок. - Київ : Вища школа, 2006. - 519 с.

30.Українська діаспора: літературні постаті, твори, біобібліографічні відомості / упоряд. В. А. Просалова. - Донецьк : Східний видавничий дім, 2012. -516 c.

31.Українська література для дітей : хрестоматія / упоряд. О. О. Гарачковська. - Київ : ВЦ «Академія», 2011. - 800 с.

32.Українська література для дітей: хрестоматія : навч. посіб. для студ. вищ. навч. закл. / упоряд. А. І. Мовчун, 3. Варавкіна. - Київ : Арій, 2011. $680 \mathrm{c}$.

33.Українське дошкілля / упоряд. Н. Зінкевич, О. Зінкевич. - Київ : Смолоскип, 2011. - 558 с.

34.Український декламатор : збірка віршів для мо́лоді / упоряд. Н. Зінкевич, О. Зінкевич ; передм. Р. Семківа. - 2-е вид. - Київ : Смолоскип, 2014. - 400 c.

35.Чередниченко Д. Хай ряст не в’яне / Д. Чередниченко // Ряст : вірші для дітей / О. Кобець. - Черкаси : Сіяч, 1993. - С. 3-4. 
36.Cuddon John Anthony. A Dictionary of Literary Terms and Literary Theory / J. A. Cuddon. - Oxford, 2013. - 784 p. 